INTER NATIONAL MONETARY FUND
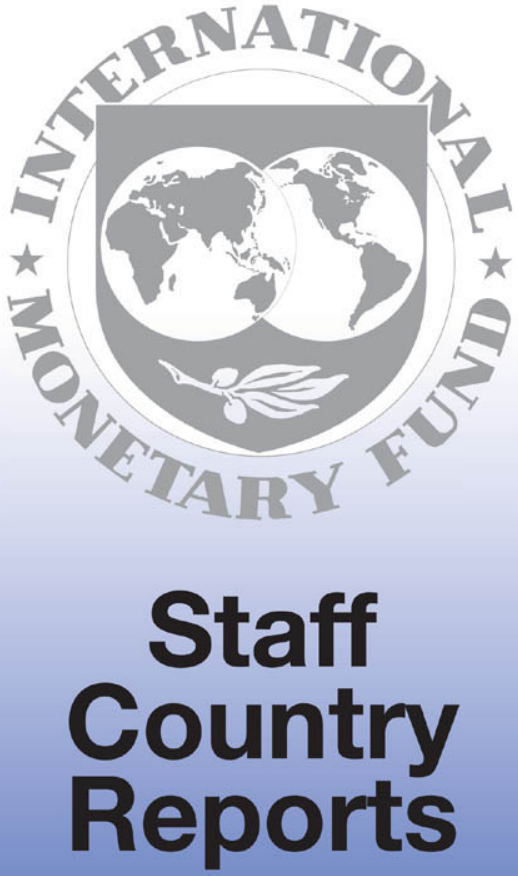


\section{Guatemala: Fourth Review Under the Stand-By Arrangement-Staff Report; Press Release on the Executive Board Discussion; and Statement by the Executive Director for Guatemala.}

In the context of the fourth review under the stand-by arrangement, the following documents have been released and are included in this package:

- $\quad$ The staff report for the Fourth Review Under the Stand-By Arrangement, prepared by a staff team of the IMF, following discussions that ended on August 26, 2010, with the officials of Guatemala on economic developments and policies. Based on information available at the time of these discussions, the staff report was completed on September 9, 2010. The views expressed in the staff report are those of the staff team and do not necessarily reflect the views of the Executive Board of the IMF.

- $\quad$ A Press Release summarizing the views of the Executive Board as expressed during its September 27, 2010 discussion of the staff report that completed the request and/or review.

- A statement by the Executive Director for Guatemala.

The document listed below has been or will be separately released.

Letter of Intent sent to the IMF by the authorities of Guatemala*

*Also included in Staff Report

The policy of publication of staff reports and other documents allows for the deletion of market-sensitive information.

Copies of this report are available to the public from

International Monetary Fund • Publication Services

$70019^{\text {th }}$ Street, N.W. • Washington, D.C. 20431

Telephone: (202) 623-7430 • Telefax: (202) 623-7201

E-mail: publications@imf.org Internet: http://www.imf.org

Price: $\$ 18.00$ a copy

\section{International Monetary Fund \\ Washington, D.C.}


INTERNATIONAL MONETARY FUND

GUATEMALA

\section{Staff Report for the Fourth Review under the Stand-By Arrangement}

Prepared by the Western Hemisphere Department

(In collaboration with other departments)

Approved by Miguel Savastano and Dominique Desruelle

September 9, 2010

\section{Executive Summary}

The economy continues to recover. The natural disasters that hit Guatemala in late May did not derail the economic recovery. Real GDP in 2010 is expected to grow by $2 \frac{1}{2}$ percent and annual inflation to reach 5.5 percent, within the target band set by the Monetary Board. The balance of payments is strengthening and the financial system remains resilient. Risks to the outlook have continued to decline.

Performance under the Stand-By Arrangement (SBA) has remained strong. All end-June 2010 quantitative performance criteria were met and annual inflation remained within the inner consultation band set in the program. The authorities have continued to treat the SBA as precautionary. Staff supports completion of the fourth and final review.

The authorities' proactive policy response to the global crisis was instrumental to support domestic demand. This helped mitigate the adverse effects of the global slowdown and created a solid basis for the recovery. The authorities indicated that the Fund's support played a key role in maintaining confidence in the economic policy mix and the strength of financial buffers.

The macroeconomic outlook is favorable, but further policy efforts are necessary. As global economic conditions improve, real GDP growth is expected to firm up. This would provide the opportunity to start fiscal consolidation to help stabilize the public debt-to-GDP ratio and regain fiscal space. A comprehensive tax reform should remain at the center of fiscal consolidation over the medium term. The completion of the banking sector reform agenda should also remain a priority. 
I. Developments Since the Third Review

II. Policy Discussions.................................................................................................. $\underline{6}$

A. Macroeconomic Outlook and Risks ........................................................................ $\frac{6}{7}$

B. Fiscal Policy .................................................................................................... $\frac{7}{7}$

C. Monetary, Exchange Rate and Financial Sector Policies............................................ 10

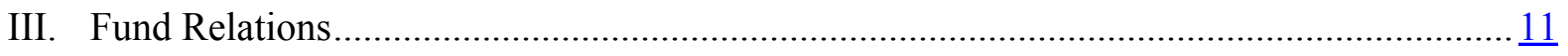

IV. Staff Appraisal .....................................................................................................

Box

1. Avoiding New Domestic Arrears ..........................................................................

Figures

1. Recent Economic Developments............................................................................ 4

2. External Sector Developments …............................................................................... $\underline{5}$

Tables

1. Selected Economic and Social Indicators................................................................. 13

2. Summary Balance of Payments............................................................................ 14

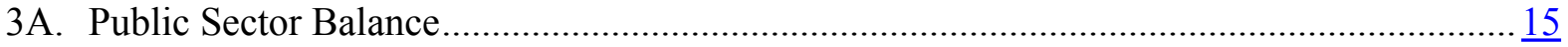

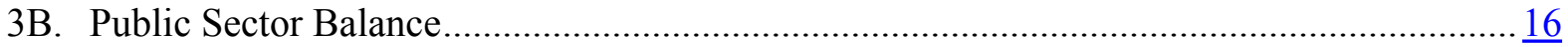

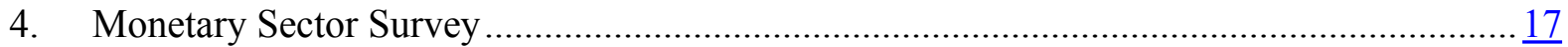

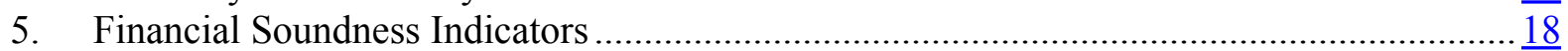

6. Indicators of External Vulnerability ...................................................................... 18

7. Schedule of Purchases under the Stand-By Arrangement .............................................. 19

8. Indicators of Fund Credit 2009-2016 .......................................................................... 19

Attachment

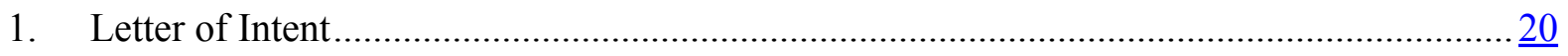




\section{DeVElopMents SinCE THE THIRD REVIEW ${ }^{1}$}

\section{Natural disasters hit Guatemala in late May, causing human and economic}

losses. The eruption of a volcano near Guatemala City and a powerful tropical storm caused losses of human lives, disrupted transportation and trade, and damaged public infrastructure and agricultural crops. Total economic losses have been estimated at 2.4 percent of GDP. ${ }^{2}$

2. The economic recovery has continued to firm up. While the natural disasters had a negative impact on the economy, they did not derail the recovery. The monthly index of economic activity (IMAE) rose to 3.1 percent (y/y) in June (up from 2.8 percent in March). Consumer price inflation remained broadly stable, with headline and core inflation at 4.1 percent and 2.6 percent (y/y), respectively, as of end-August (Figure 1).

3. A new Minister of Finance, Mr. Edgar Balsells, took office in late June. Minister Balsells indicated to the mission that he is committed to maintain prudent fiscal policies. His priorities in the near term will be to accommodate relief and reconstruction spending associated with the natural disasters, contain non-priority spending to help meet the 2010 fiscal deficit target, seek approval of the draft 2011 budget (submitted to congress in early September), avoid new domestic payment arrears by the government, and secure congressional support for an anti-tax evasion law.

\section{Balance of payments flows have} continued to normalize. Growth in exports and imports is accelerating, and remittances have begun to recover. The balance of payments is estimated to have posted a surplus of about US\$500 million in the first half of the year, taking net international reserves 10 percent above end-2009 levels (Figure 2). The exchange rate has remained broadly stable since March despite limited central bank intervention in the foreign exchange

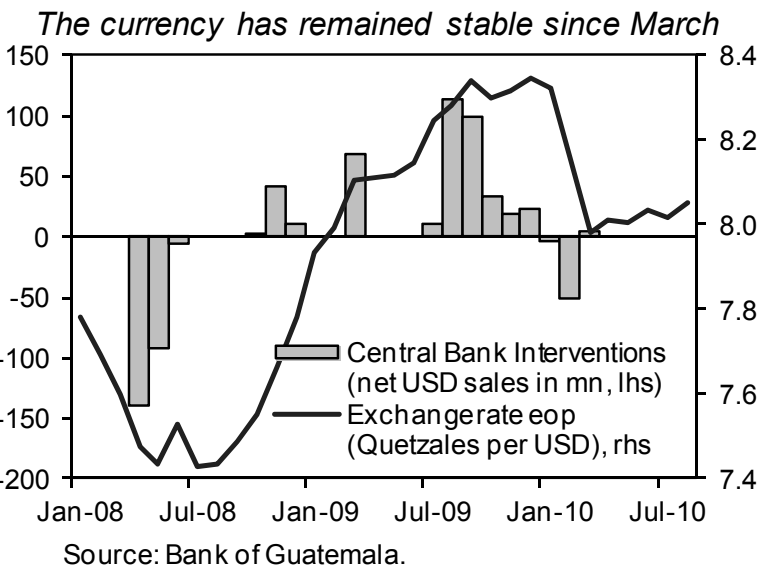
market under the rules-based framework.

\footnotetext{
${ }^{1}$ Discussions on the fourth review were held in Guatemala City during August 16-26. The mission comprised Mr. López Mejía (Head), Ms. Medina Cas, Mr. Morra (all WHD), Mr. Henn (SPR), and was assisted by Mr. Delgado (Regional Resident Representative). The mission met with Central Bank President de Bonilla, Minister of Finance Balsells, Superintendent of Banks Barquín, other senior officials, and representatives of the private sector. Mr. Gramajo (OED) joined key policy meetings.

${ }^{2}$ Estimate prepared by a team of experts from the Economic Commission for Latin America and the Caribbean, the World Bank, and the Inter-American Development Bank.
} 
Figure 1. Guatemala: Recent Economic Developments

The economic recovery continues.

Economic activity continues its gradual recovery ...

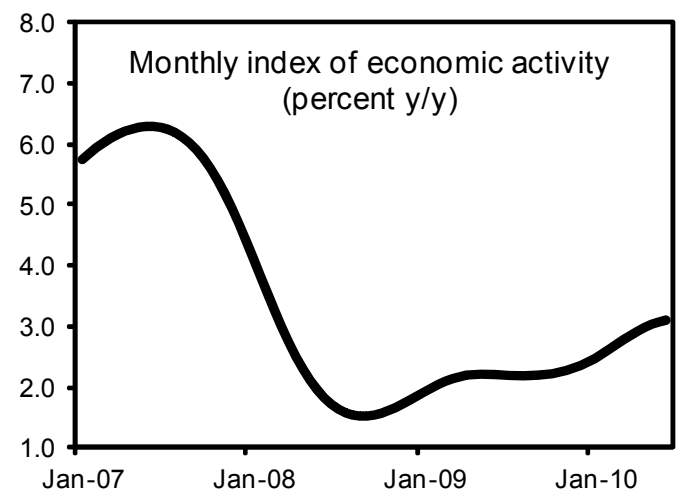

The recovery is raising tax collections.

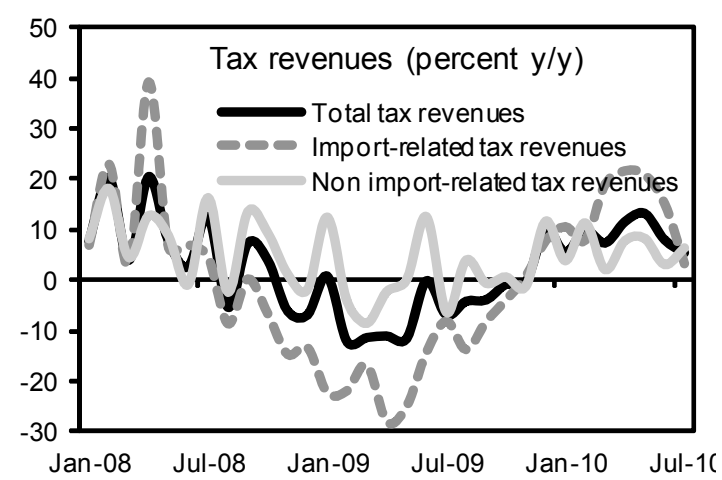

Bank deposits are rising ...

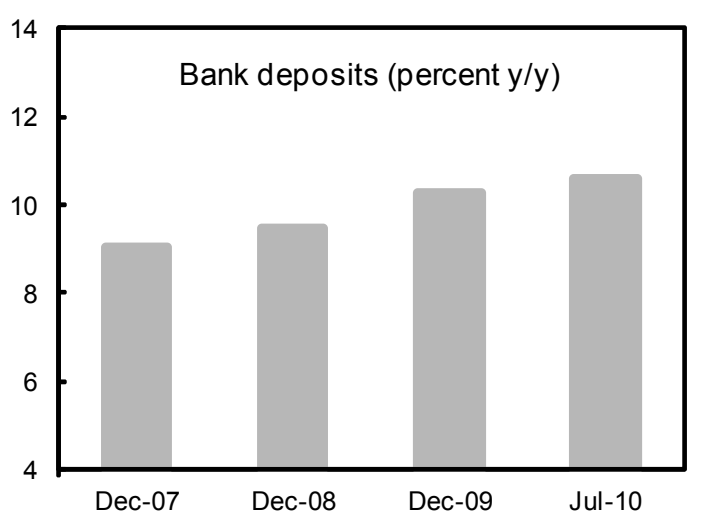

$\ldots$ and trade is rebounding.

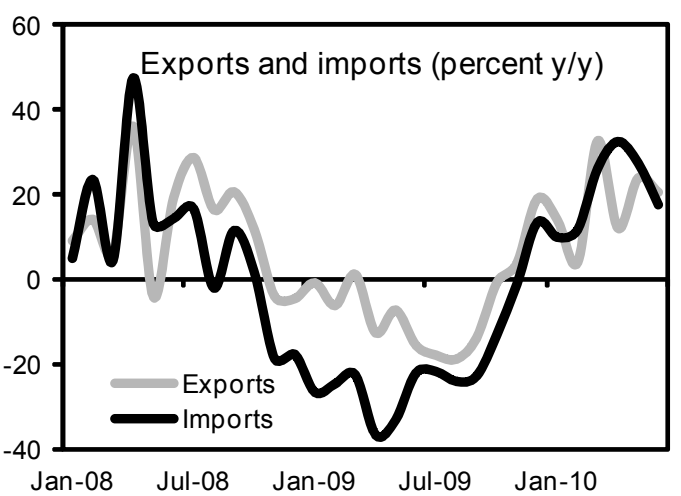

Inflation has picked up, but remains below the target range.

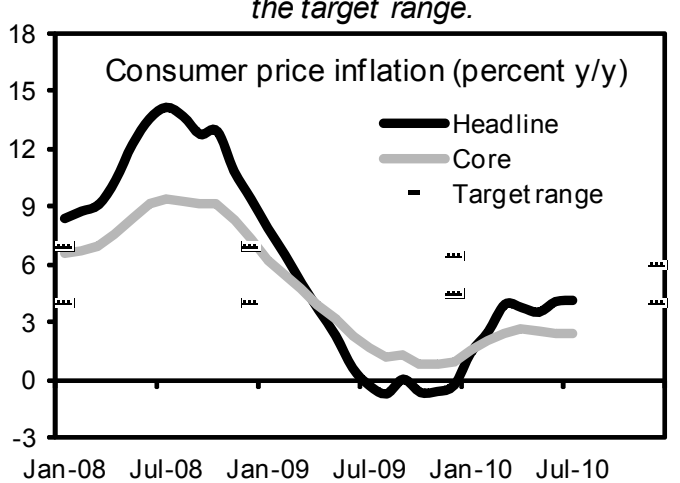

... but credit to the private sector remains sluggish.

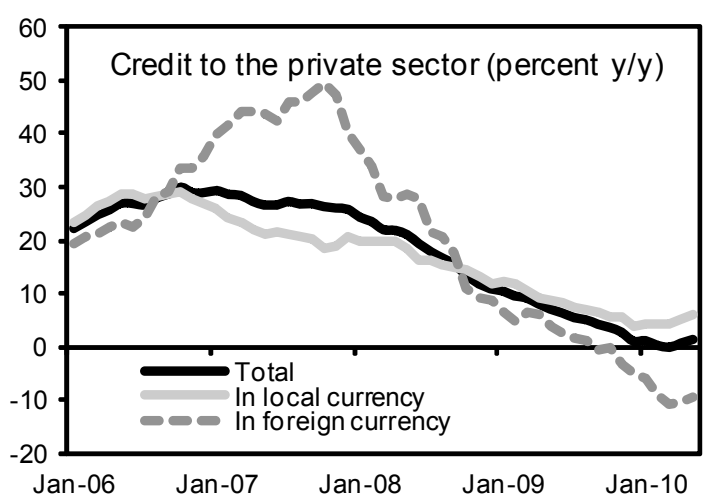

Source: Fund staff based on national authorities. 
Figure 2. Guatemala: External Sector Developments

The balance of payments continues to strengthen.

Private capital flows are recovering.

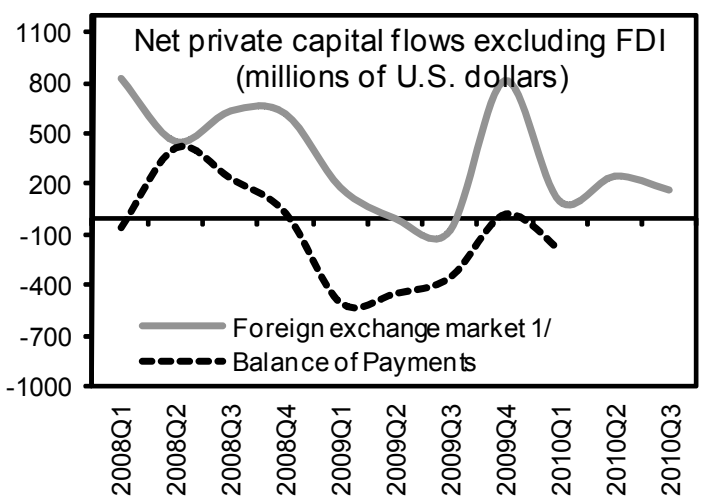

... as imports continued to rebound ...

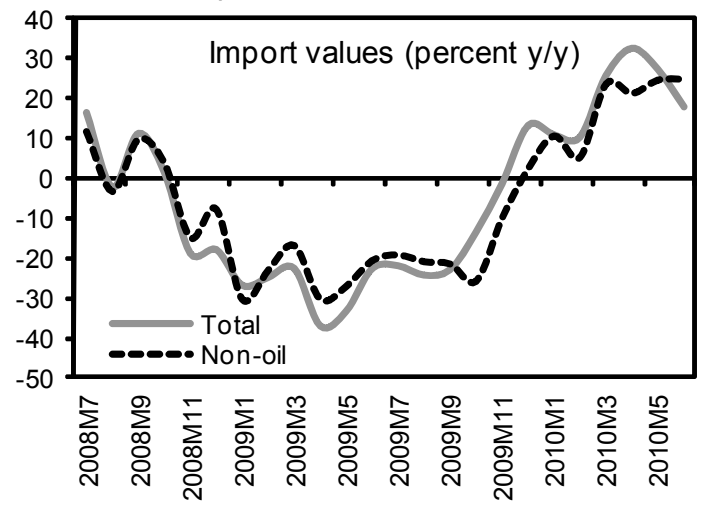

Remittances are recovering ...

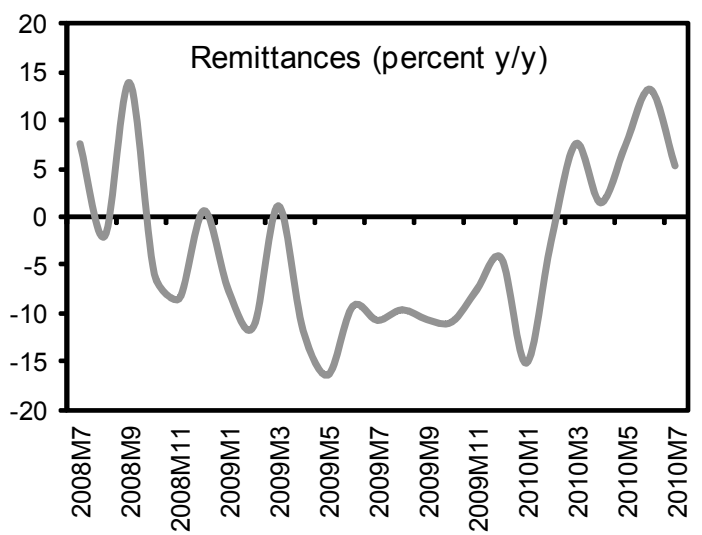

The current account posted a deficit in the first half of the year, ...

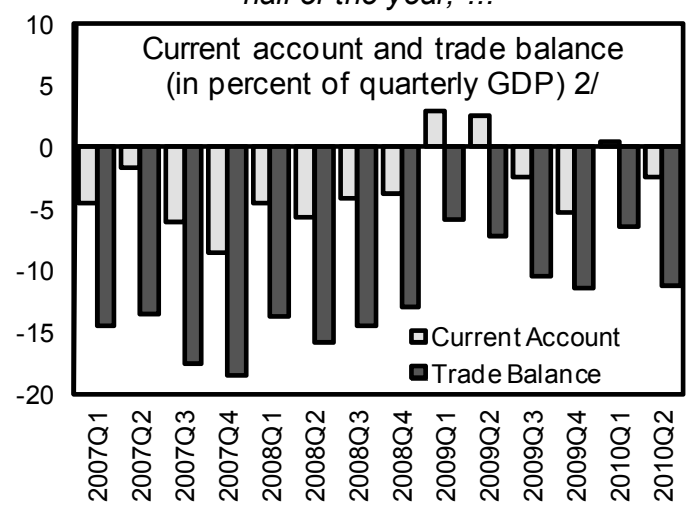

... broadly in tandem with exports.

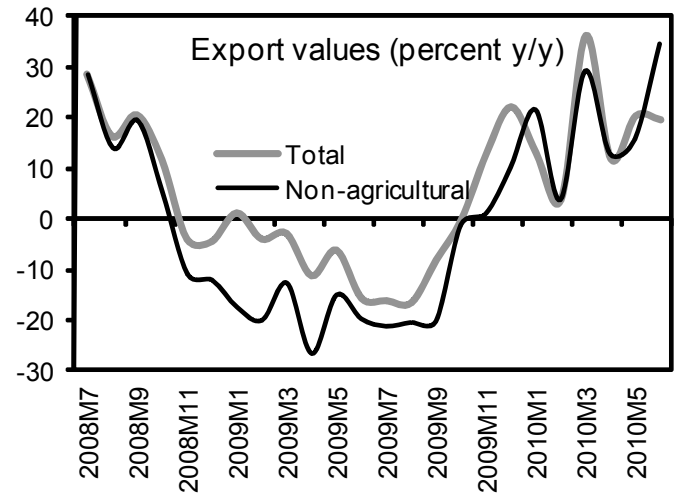

... and international reserves continue increasing.

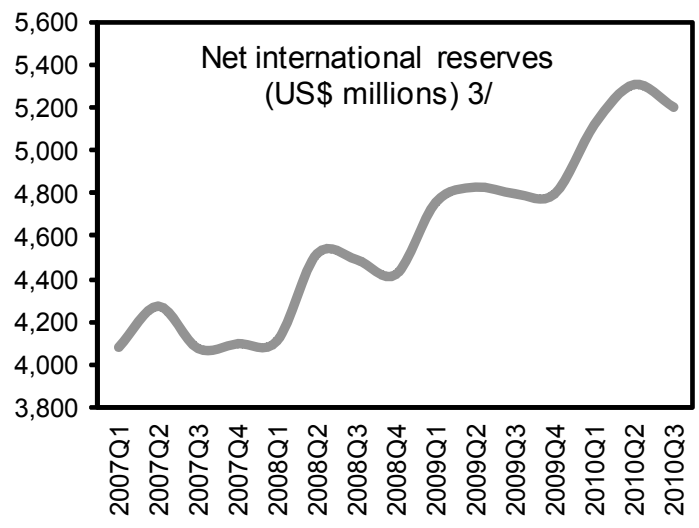

Sources: Bank of Guatemala, and Fund staff estimates.

1/ 2010Q3 observation covers flows through August 12.

2/ 2010Q2 observation estimated based on available merchandise trade and remittances data.

3/ 2010Q3 observation depicts stock as of August 24. 
5. The fiscal deficit in the first semester was lower than envisaged in the program. The deficit of the central government through June 2010 reached 0.9 percent of annual GDP, lower than the 1.5 percent of GDP projected in the program. This outturn was largely explained by delays in obtaining congressional authorization for the financing necessary to undertake the spending envisaged for the year (consistent with a deficit of 3.1 percent of GDP). ${ }^{3}$

\section{The financial system remains}

resilient. Bank capitalization and liquidity indicators remain sound. As of June, nonperforming loans stood at 2.8 of total loans, down from a peak of 3.2 percent in October 2009. Bank profitability is increasing (with returns on equity and on assets of 18.1 and 1.9 percent, respectively, as of June 2010). Bank deposits continue growing at a healthy pace (10.6 percent $y / y$ in July), but credit growth to the private sector remains

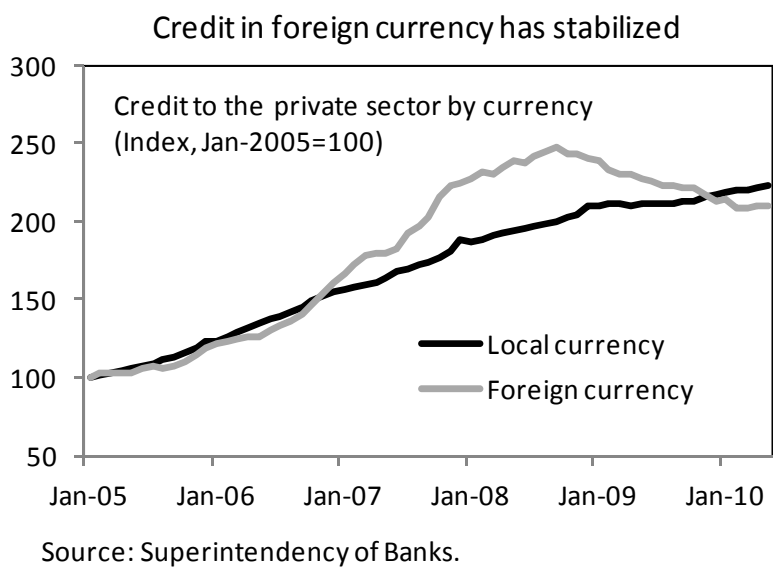
sluggish (1.7 percent $y / y$ in July). The sharp reduction in lending in foreign currency observed in 2009- associated with lower trade-related financing, tighter credit standards, and a reduction of foreign-currency exposures - appears to be abating (-7.1 percent $y / y$ in July), while credit in local currency is picking up (6.2 percent $y / y$ in July). In addition, there is some evidence that international banks operating in the region have increased lending in foreign currency.

7. Program implementation remained strong. All quantitative performance criteria for end-June 2010 were met. The annual rate of inflation stood within the inner consultation band, and government deposits at the central bank exceeded the indicative target set in the program.

\section{POLICY Discussions}

\section{A. Macroeconomic Outlook and Risks}

\section{The macroeconomic outlook has not been affected materially by the natural} disasters of last May. Real GDP is projected to grow by about 2⿺辶2 percent in 2010 and 2011. Annual inflation is projected to end the year at 5.5 percent, within the target band set by the Monetary Board. Terms of trade gains will help limit the increase in the external current account deficit in 2010 to 2.9 percent of GDP (up from - 0.6 percent of GDP in 2009), though

\footnotetext{
${ }^{3}$ Congress approved the issuance of domestic bonds for Q4.5 billion (1.4 percent of GDP) only in May.
} 
the deficit is projected to increase further in 2011. Private capital inflows are projected to average 2 percent of GDP per year in 2010-11, on the back of firmer FDI. Unrecorded inflows (errors and omissions) are expected to abate as the authorities continue improving data collection. Net international reserves are projected to reach US $\$ 5.2$ billion at end-2010, and to rise by another US $\$ 0.2$ billion in
The recovery is taking hold

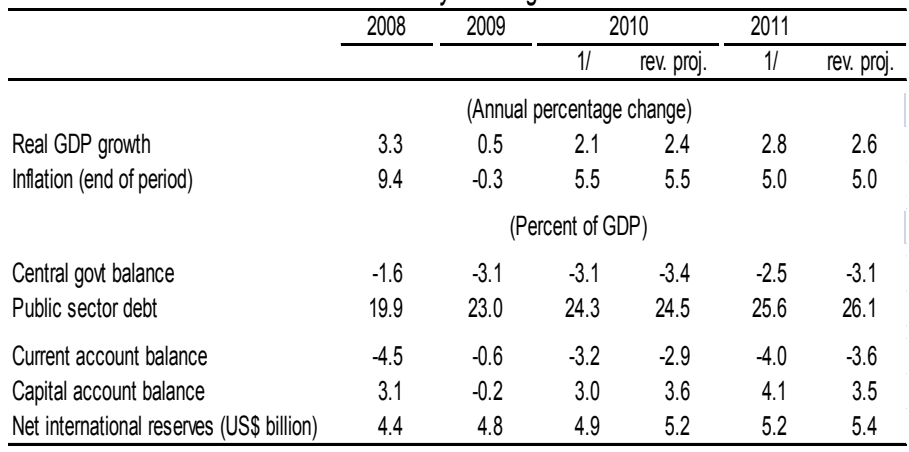

Sources: Bank of Guatemala; Ministry of Finance; and Fund staff projections.

1/ Staff Report for the Third Review under the SBA.

2011. External debt service payments remain manageable.

9. Risks to the outlook have declined. The ongoing recovery in exports and remittances and the pickup in FDI flows have lowered risks to the balance of payments and activity. The main downside risks to the outlook come from a more sluggish-than-projected economic recovery in the United States, a sharp increase in oil prices, and heightened political uncertainty ahead of the September 2011 presidential elections.

\section{B. Fiscal Policy}

10. The authorities raised their 2010 target for the central government deficit to 3.4 percent of GDP (from 3.1 percent of GDP previously) to accommodate the demand for relief and reconstruction expenditures. Excluding reconstruction spending ( 0.3 percent of GDP for this year), the deficit target is broadly the same as the one projected during the third review. With this revised target, the primary deficit in 2010 would rise to 1.8 percent of GDP, and the discretionary stimulus $(0.5$ percent

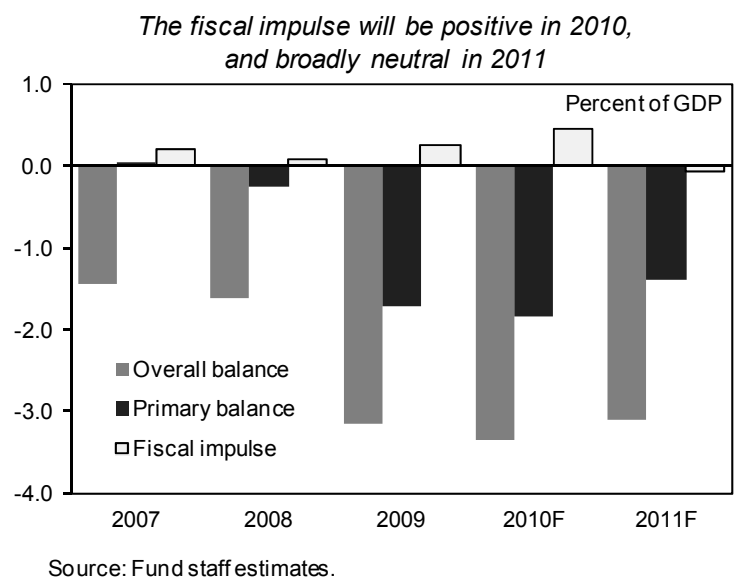
of GDP) will more than offset the cyclical rebound in revenues. As a result, the fiscal stance in 2010 would now be modestly expansionary, and public debt by end-2010 will rise to $24 \frac{1}{2}$ percent of GDP (from 20 percent of GDP at end-2008). ${ }^{4}$

\footnotetext{
${ }^{4}$ These projections assume that congress will authorize the new government borrowing necessary to finance the higher expenditure plans for the second half of the year. If the approval is not forthcoming, the fiscal deficit in 2010 may be below 3 percent of GDP.
} 
11. The draft 2011 budget recently submitted to Congress would result in a modest start of the consolidation process. The draft envisages a small decline in the central government deficit in 2011, which would imply a broadly neutral policy stance. The draft budget, which excludes reconstruction expenditures, would imply a deficit of 2.7 percent of GDP, higher than the target in the medium-term budget framework presented by the authorities last May (2.5 percent of GDP). ${ }^{5}$ The mission welcomed the authorities' intention to lower the fiscal deficit in 2011, but recommended a more ambitious pace of consolidation. Staff stressed that a faster pace of consolidation would signal a strong commitment by the government to stabilize the public debt-to-GDP ratio and regain fiscal space. The authorities agreed that it was desirable to lower the fiscal deficit to pre-crisis levels over the medium term, but considered that a more ambitious pace of consolidation in 2011 was not feasible given the rigidity of several expenditure categories and ongoing spending pressures.

\section{Staff reiterated that a comprehensive tax reform should remain at the center of} fiscal consolidation. Although political resistance to tax reform remains strong, the authorities indicated that they will continue working with congress to build support for some of the measures proposed in the draft law submitted last November, including the increases in income and stamp tax rates. In addition, the authorities intend to seek approval of measures aimed at reducing tax evasion, strengthening tax administration and improving the small tax-payers VAT scheme. The mission welcomed these initiatives, but stressed that a comprehensive revenue-enhancing reform remained necessary to ensure sustainable public debt dynamics, particularly given the higher level of current spending (largely reflecting higher social expenditure) the government seeks to maintain. In the absence of new revenues, the burden of reducing the fiscal deficit to below 2 percent of GDP (the debt-stabilizing level) would have to fall on social and capital expenditures, which are low.

\section{There was agreement on the importance of adopting measures to avoid new} domestic arrears and regularize the outstanding stock. Staff welcomed the authorities' intention to undertake several actions recommended by the recent Fund technical assistance mission on domestic arrears (Box 1). In particular, the authorities indicated that they plan to tighten legislation and controls, introduce (and enforce) stricter sanctions, seek passage of a draft law to regulate public trust funds, and phase out contracts signed under the old procurement law. The mission also supported the authorities' intention to conduct an audit to quantify and assess the legitimacy of outstanding arrears and stressed the importance that the audit be undertaken by an internationally recognized firm. In addition, staff suggested that the clearance of outstanding arrears be done through the issuance of domestic bonds and that future budget allocations penalize the entities that have been more prone to generate arrears. The mission also recommended to strengthen the role of the ministry of finance in the enabling regulations of the law on Private-Public Partnerships approved earlier this year.

\footnotetext{
${ }^{5}$ The reconstruction expenditures and their financing are expected to be included in a draft law to be submitted to congress before the end of the year.
} 


\section{Box 1: Avoiding New Domestic Arrears}

Public sector arrears are a chronic problem in Guatemala and appear to have increased in the last three years. A recent Fund technical assistance mission helped the authorities identify the sources of these arrears and recommended measures to prevent their recurrence. The key findings and recommendations of the mission are summarized below.

\section{Sources}

Government arrears in Guatemala are of two types. The first, the most common, is generated by government entities committing resources for the purchase of goods or services that are not contemplated in the budget or covered by financial information systems. These arrears are rarely sanctioned, and are difficult to quantify and control. The second type of arrears arises during budget execution possibly as a result of unexpected reductions in revenues and weaknesses in public financial management.

\section{Remedial Measures}

To avoid the first type of arrears, it would be critical to:

- Tighten legislation and administrative controls. This would help ensure that line ministries do not engage in contracts and purchases without proper budgetary allocations and recording. To enforce this control, it would be important to issue norms that declare illegal any contract and purchase order not accompanied by a "certificate of budget availability" issued by the ministry of finance and/or not recorded in the financial information system.

- Impose (and enforce) stricter sanctions on public officials that do not comply with budget and procurement rules and regulations.

To avoid the second type of arrears, it would be important to:

- Increase budget flexibility including by establishing a contingency reserve and an emergency fund to accommodate unanticipated expenditures.

- Improve the control of budget execution including by recording all expenditures and obligations when they accrue (and not only when payments are made).

- Improve cash and liquidity management, including by increasing the coverage of the single treasury account and improving coordination with spending units.

- Phase out contracts signed under the old procurement law and gradually eliminate the role of trust funds in budget execution. 


\section{Monetary, Exchange Rate and Financial Sector Policies}

\section{Staff and the authorities} agreed that monetary policy should remain vigilant. The monetary policy rate has been kept at 4.5 percent since September 2009, while inflation expectations have begun to increase from December 2009 to April 2010. Since then, inflation expectations have broadly converged to 6 percent, the upper bound of the inflation target range set by the Monetary Board. Staff and the authorities concurred that the

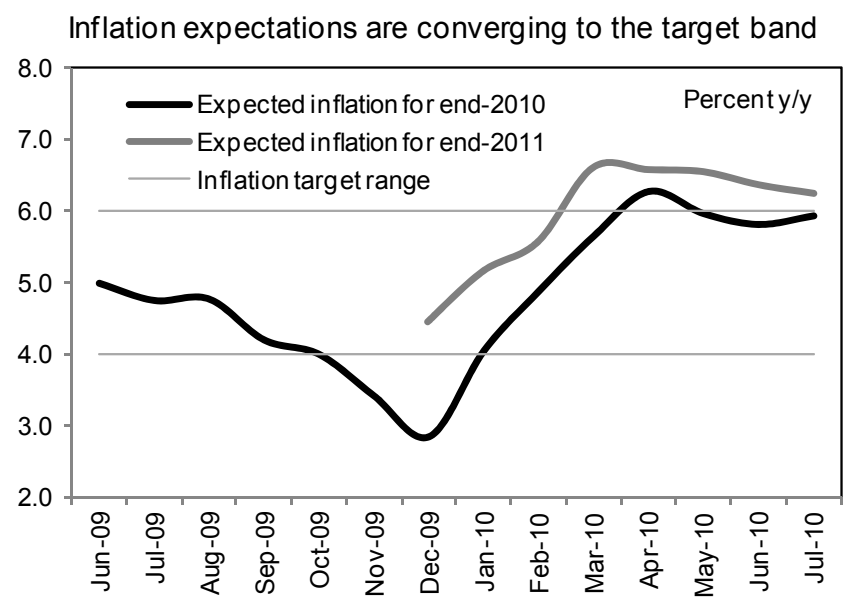

Source: Bank of Guatemala. convergence in inflation expectations, sluggish credit growth, and a still negative output gap suggested that the monetary policy stance remained appropriate. However, there also was agreement on the need to continue monitoring closely inflation expectations and capital flows, and stand ready to raise the policy rate if conditions change. ${ }^{6}$

\section{There was agreement on the importance to continue strengthening the monetary} policy framework, including maintaining exchange rate flexibility. The mission welcomed the authorities' efforts to further develop a yield curve and their commitment to exchange rate flexibility, which helped cushion the impact of the global economic crisis and is key to enhance the channels of transmission of monetary policy. A transitional framework for monetary operations (comprising daily auctions of seven-day instruments) may come into place in October. The mission concurred with the authorities that the fully upgraded framework (centered on an overnight interest rate) should be put in place once the central bank and the market are confident that procedures and systems are working satisfactorily.

\section{Financial sector reforms have continued to advance, though key elements of the} reform agenda remain pending. A new insurance law, enhancing the capacity of the Superintendency of Banks to effectively supervise insurance intermediaries and products, was approved in July. Progress has also been made in implementing the regulations on liquidity and foreign currency credit risk management, and plans to reach full provisioning of nonperforming loans by 2011 remain on schedule. The authorities are also preparing regulations to further strengthen information technology risk, banks' risk governance and comprehensive risk management; these regulations are expected to be approved by end- 2010 .

\footnotetext{
${ }^{6}$ As required by law, the term of the current central bank president ends on September 30. President Colom should appoint a successor (or reappoint the current president) in the coming weeks.
} 
The mission encouraged the authorities to step up efforts to seek prompt congressional approval for the amendments to the banking law, which are essential to further strengthen the resilience of the banking sector. Staff reiterated its recommendation of enhancing crisis preparedness, including by preparing a systemic banking resolution plan.

\section{FUND RELATIONS}

17. The authorities considered that the SBA had been useful. In particular, they were of the view that Fund support played a key role in maintaining confidence in the consistency of policies and the strength of financial buffers, and allowed them to focus the policy response on mitigating the effects of the global slowdown. The authorities indicated their interest in exploring options for continued engagement with the Fund, including under the new lending facilities that were recently approved by the Board.

\section{STAFF APpraisal}

18. The recovery of the Guatemalan economy continues to firm up. Although the natural disasters that hit Guatemala in late May caused human losses and had a negative impact on the economy, they did not derail the recovery. Economic activity is gaining steam and inflation has stabilized. External trade is rebounding, remittances have begun to recover, and the overall balance of payments is strengthening. In addition, the financial system remains resilient, and credit to the private sector in local currency is gradually picking up.

19. Performance under the SBA has remained strong. All quantitative performance criteria for end-June 2010 were met. The annual rate of inflation stood within the inner consultation band, and government deposits at the central bank exceeded the indicative target set in the program. The authorities plan to continue treating the SBA as precautionary. Even if Guatemala were to draw the full amount available under the program, they would be in a strong position to repay the Fund.

20. The near-term outlook is favorable, and risks to the outlook have declined. Real GDP is projected to grow by about $2 \frac{1}{2}$ percent during $2010-11$ driven by domestic demand, and improved global financial conditions have lowered risks to the balance of payments. The main downside risks stem from more-sluggish-than projected growth in the United States, a sharp increase in oil prices, and heightened political uncertainty ahead of the presidential elections in 2011.

21. The small withdrawal of fiscal stimulus that was envisaged for 2010 will not take place. The deficit of the central government in 2010 is now projected at 3.4 percent of GDP, somewhat higher than projected earlier, due to relief and reconstruction expenditures associated with the natural disasters. This higher deficit will provide some additional stimulus to domestic demand this year and postpone the withdrawal of stimulus to 2011 . 
22. A comprehensive revenue reform remains a key priority. Seeking approval of an anti-evasion law and of some elements of the draft law submitted to congress last November would be positive steps, but a comprehensive revenue reform remains necessary. Higher revenues would help stabilize the public debt-to-GDP ratio and avoid that the burden of fiscal consolidation falls on social and capital expenditures. While the draft budget for 2011 would help shift the fiscal stance, it would be desirable to set a more ambitious target to send a strong signal about the government's commitment to fiscal consolidation. Staff also urges the authorities to find a prompt solution to the problem of domestic arrears, which weakens the budgetary and fiscal framework.

23. Monetary policy should remain vigilant. Stable inflation expectations, a negative output gap and slow credit growth suggest that the monetary policy stance remains broadly appropriate. Staff agrees with the authorities on the importance to continue monitoring closely monetary indicators, capital flows, and inflation expectations, and to stand ready to tighten the policy stance, if needed. Staff welcomes the authorities' continued commitment to exchange rate flexibility, which is essential to absorb shocks and to strengthen the inflationtargeting framework.

24. The financial sector reform agenda should remain a priority. Staff welcomes the recent adoption of the regulations on liquidity and foreign-currency credit risk management, the continued progress towards full provisioning of nonperforming loans, and the approval of a law governing the insurance sector. Securing congressional approval of the draft amendments to the banking law would be key to further increase the resilience of the banking sector. Increasing crisis preparedness, including by putting together a systemic banking resolution plan, is also important.

\section{Staff recommends completion of the Fourth Review under the SBA.}


Table 1. Guatemala: Selected Economic and Social Indicators

\begin{tabular}{|c|c|c|c|c|c|c|c|}
\hline \multirow[t]{4}{*}{$\begin{array}{l}\text { Population } 2009 \text { (millions) } \\
\text { Percentage of indigenous population (2006) } \\
\text { Population below the poverty line (Percent, 2006) } \\
\text { Rank in UNDP development index (2009) }\end{array}$} & $\begin{array}{c}14.3 \\
38.4 \\
51.0 \\
122 \text { of } 182\end{array}$ & & $\begin{array}{l}\text { Gini index } \\
\text { Life expect } \\
\text { Adult illiter } \\
\text { GDP per c }\end{array}$ & $\begin{array}{l}6) \\
\text { at birt } \\
\text { rate }(20 \\
\text { (US\$, }\end{array}$ & $\begin{array}{l}\text { 2007) } \\
08)\end{array}$ & $\begin{array}{r}53.7 \\
70.1 \\
26.8 \\
2,850\end{array}$ & \\
\hline & \multicolumn{7}{|c|}{ II. Economic Indicators } \\
\hline & \multirow[t]{2}{*}{2007} & \multirow[t]{2}{*}{2008} & \multirow[t]{2}{*}{2009} & \multicolumn{2}{|c|}{2010} & \multicolumn{2}{|c|}{2011} \\
\hline & & & & $1 /$ & v. proj. & $1 /$ & Rev. proj. \\
\hline & \multicolumn{7}{|c|}{ (Annual percent change) } \\
\hline \multicolumn{8}{|l|}{ Income and prices } \\
\hline Real GDP & 6.3 & 3.3 & 0.5 & 2.1 & 2.4 & 2.8 & 2.6 \\
\hline Consumer prices (end of period) & 8.7 & 9.4 & -0.3 & 5.5 & 5.5 & 5.0 & 5.0 \\
\hline \multicolumn{8}{|l|}{ Monetary sector } \\
\hline M2 & 10.2 & 7.6 & 10.0 & 9.9 & 10.9 & 9.4 & 10.6 \\
\hline \multirow[t]{2}{*}{ Credit to the private sector } & 26.0 & 11.0 & 1.1 & 6.4 & 4.6 & 10.8 & 7.2 \\
\hline & & (In perc & cent of GDF & less ot & wise in & ated) & \\
\hline Savings and investment & & & & & & & \\
\hline Gross domestic investment & 20.8 & 16.4 & 12.9 & 15.3 & 15.9 & 17.0 & 16.9 \\
\hline Private sector & 17.2 & 13.2 & 9.9 & 12.7 & 12.7 & 13.8 & 14.1 \\
\hline Public sector & 3.6 & 3.2 & 3.1 & 2.6 & 3.2 & 3.1 & 2.9 \\
\hline Gross national saving & 15.6 & 11.8 & 12.4 & 12.1 & 13.0 & 13.0 & 13.3 \\
\hline Private sector & 12.3 & 9.4 & 12.1 & 11.2 & 12.9 & 11.9 & 12.9 \\
\hline Public sector & 3.3 & 2.5 & 0.3 & 0.9 & 0.2 & 1.1 & 0.4 \\
\hline External saving & 5.2 & 4.5 & 0.6 & 3.2 & 2.9 & 4.0 & 3.6 \\
\hline External sector & & & & & & & \\
\hline Current account balance & -5.2 & -4.5 & -0.6 & -3.2 & -2.9 & -4.0 & -3.6 \\
\hline Trade balance (goods) & -16.1 & -14.2 & -8.8 & -10.5 & -10.5 & -12.5 & -11.6 \\
\hline Exports & 20.5 & 20.0 & 19.5 & 19.5 & 20.1 & 19.3 & 20.8 \\
\hline Imports & -36.6 & -34.3 & -28.2 & -30.0 & -30.6 & -31.8 & -32.4 \\
\hline of which: oil \& lubricants & -6.7 & -6.8 & -5.5 & -6.6 & -5.8 & -6.8 & -6.3 \\
\hline Other (net) & 10.9 & 9.7 & 8.2 & 7.3 & 7.6 & 8.5 & 8.0 \\
\hline of which: remittances & 12.3 & 11.2 & 10.6 & 10.3 & 10.2 & 11.5 & 10.5 \\
\hline Capital and financial account & 4.7 & 3.1 & -0.2 & 3.0 & 3.6 & 4.1 & 3.5 \\
\hline Public sector & 0.7 & 0.3 & 2.1 & 1.4 & 1.9 & 1.5 & 1.2 \\
\hline Private sector & 4.0 & 2.8 & -2.3 & 1.6 & 1.7 & 2.6 & 2.3 \\
\hline of which: FDI & 2.1 & 1.9 & 1.4 & 1.4 & 1.6 & 1.5 & 1.6 \\
\hline Errors and omissions & 1.2 & 2.3 & 2.1 & 0.5 & 0.5 & 0.5 & 0.5 \\
\hline Overall balance & 0.6 & 0.8 & 1.3 & 0.3 & 1.2 & 0.7 & 0.5 \\
\hline Net international reserves & & & & & & & \\
\hline (Stock in months of next-year NFGS imports) & 3.2 & 4.2 & 4.0 & 3.9 & 4.0 & 3.7 & 3.7 \\
\hline (Stock over short-term debt on residual maturity) & 1.0 & 1.0 & 1.4 & 1.3 & 1.4 & 1.3 & 1.3 \\
\hline $\begin{array}{l}\text { Public finances } \\
\text { Central government }\end{array}$ & & & & & & & \\
\hline Revenues & 12.8 & 12.0 & 11.1 & 11.3 & 11.3 & 11.5 & 11.7 \\
\hline Expenditures & 14.3 & 13.6 & 14.2 & 14.3 & 14.7 & 14.0 & 14.8 \\
\hline Current & 9.5 & 9.2 & 10.1 & 10.8 & 10.6 & 10.9 & 11.0 \\
\hline Capital & 4.8 & 4.5 & 4.1 & 3.5 & 4.1 & 3.1 & 3.8 \\
\hline of which: reconstruction & n.a. & n.a. & n.a. & 0.0 & 0.3 & 0.0 & 0.4 \\
\hline Primary balance & 0.0 & -0.3 & -1.7 & -1.5 & -1.8 & -0.9 & -1.4 \\
\hline Overall balance & -1.4 & -1.6 & -3.1 & -3.1 & -3.4 & -2.5 & -3.1 \\
\hline Overall balance (without reconstruction) & n.a. & n.a. & n.a. & -3.1 & -3.1 & -2.5 & -2.7 \\
\hline Financing of the central government balance & 1.4 & 1.6 & 3.1 & 3.1 & 3.4 & 2.5 & 3.1 \\
\hline Net external financing & 1.2 & 0.3 & 1.3 & 1.4 & 1.9 & 1.0 & 1.2 \\
\hline Net domestic financing & 0.3 & 1.3 & 1.8 & 1.7 & 1.5 & 1.5 & 1.9 \\
\hline of which: use of government deposits & -0.7 & 0.8 & 0.4 & 0.3 & 0.0 & 0.0 & 0.3 \\
\hline $\begin{array}{l}\text { Rest of nonfinancial public sector balance } \\
\text { Combined nonfinancial public sector }\end{array}$ & 1.1 & 0.9 & 0.4 & 0.5 & 0.5 & 0.5 & 0.5 \\
\hline Primary balance & 1.2 & 0.6 & -1.3 & -1.0 & -1.3 & -0.4 & -0.9 \\
\hline Overall balance & -0.3 & -0.7 & -2.8 & -2.5 & -2.8 & -2.0 & -2.6 \\
\hline Nonfinancial public sector debt & 21.3 & 19.9 & 23.0 & 24.3 & 24.5 & 25.6 & 26.1 \\
\hline External & 12.1 & 11.0 & 13.0 & 13.5 & 13.8 & 14.0 & 14.5 \\
\hline Domestic & 9.2 & 8.9 & 10.0 & 10.8 & 10.7 & 11.5 & 11.6 \\
\hline Memorandum items: & & & & & & & \\
\hline GDP (US $\$$ billions) & 34.1 & 39.1 & 37.7 & 40.0 & 40.8 & 41.7 & 42.6 \\
\hline
\end{tabular}

Sources: Bank of Guatemala; Ministry of Finance; and Fund staff estimates and projections.

1/ Staff Report for the Third Review under the SBA. 
Table 2. Guatemala: Summary Balance of Payments

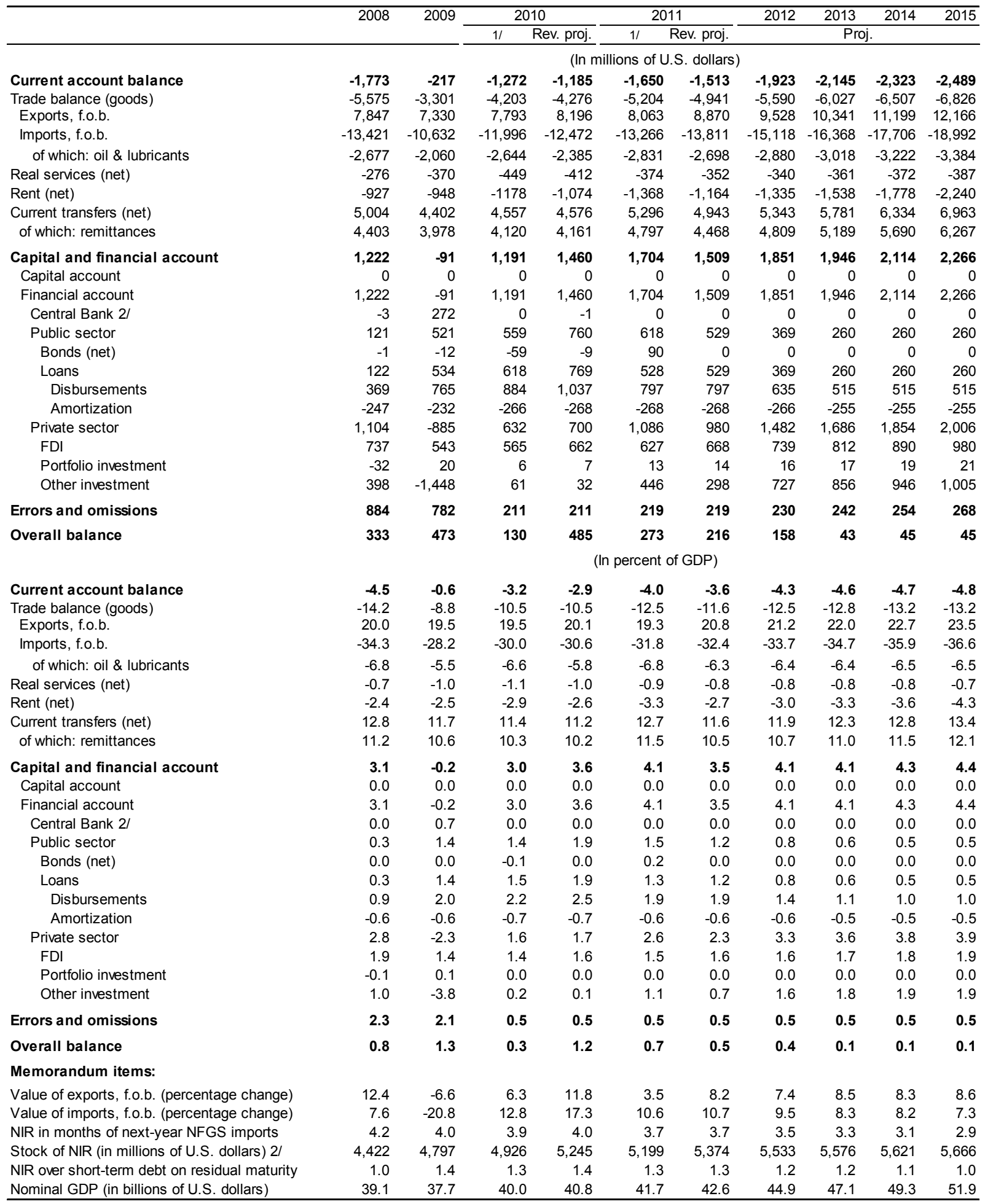

Sources: Central Bank of Guatemala; Ministry of Finance; and Fund staff estimates and projections.

1/ Staff Report for the Third Review under the SBA.

2/ Includes 2009 SDR allocations of US\$271 million. 
Table 3A. Guatemala: Public Sector Balance

\begin{tabular}{|c|c|c|c|c|c|c|c|}
\hline & \multirow{2}{*}{2007} & \multirow[t]{2}{*}{2008} & \multirow[t]{2}{*}{2009} & \multicolumn{2}{|c|}{2010} & \multicolumn{2}{|c|}{2011} \\
\hline & & & & $1 /$ & Rev. proj. & $1 /$ & Rev. proj. \\
\hline & \multicolumn{7}{|c|}{ (In millions of quetzales ) } \\
\hline \multicolumn{8}{|l|}{ Central Government } \\
\hline Total revenues & 33,611 & 35,578 & 34,037 & 36,630 & 37,399 & 40,055 & 41,426 \\
\hline Tax revenues & 31,543 & 33,358 & 31,812 & 34,325 & 34,996 & 37,599 & 38,348 \\
\hline Nontax revenues & 2,067 & 2,220 & 2,225 & 2,305 & 2,403 & 2,455 & 3,078 \\
\hline Total expenditures & 37,382 & 40,355 & 43,709 & 46,563 & 48,503 & 48,907 & 52,448 \\
\hline Current & 24,781 & 27,134 & 31,161 & 35,233 & 35,003 & 38,089 & 39,102 \\
\hline Wages & 8,226 & 9,260 & 11,154 & 12,123 & 12,605 & 13,261 & 13,323 \\
\hline Goods \& services & 3,496 & 5,235 & 5,686 & 6,500 & 5,800 & 6,979 & 7,389 \\
\hline Social security benefits & 2,005 & 2,347 & 2,776 & 3,357 & 3,358 & 3,400 & 3,950 \\
\hline Interest & 3,892 & 4,026 & 4,374 & 5,060 & 5,050 & 5,760 & 6,045 \\
\hline Transfers & 7,076 & 6,165 & 7,086 & 8,127 & 8,100 & 8,654 & 8,326 \\
\hline Other & 86 & 102 & 84 & 66 & 90 & 35 & 70 \\
\hline Capital & 12,602 & 13,221 & 12,548 & 11,330 & 13,500 & 10,818 & 13,346 \\
\hline of which: reconstruction & n.a. & n.a. & n.a. & 0 & 980 & 0 & 1,300 \\
\hline Primary expenditures & 33,491 & 36,329 & 39,335 & 41,503 & 43,453 & 43,147 & 46,403 \\
\hline Primary balance & 120 & -751 & $-5,297$ & $-4,873$ & $-6,055$ & $-3,092$ & $-4,978$ \\
\hline Overall balance & $-3,772$ & $-4,777$ & $-9,672$ & $-9,933$ & $-11,105$ & $-8,852$ & $-11,023$ \\
\hline Overall balance (without reconstruction) & n.a. & n.a. & n.a. & $-9,933$ & $-10,125$ & $-8,852$ & $-9,723$ \\
\hline Financing & 3,772 & 4,777 & 9,672 & 9,933 & 11,105 & 8,852 & 11,023 \\
\hline Net external financing & 3,040 & 850 & 4,117 & 4,434 & 6,278 & 3,616 & 4,402 \\
\hline Loans & 3,040 & 850 & 4,117 & 4,434 & 6,278 & 2,153 & 4,402 \\
\hline Disbursements & 4,613 & 2,763 & 6,273 & 6,560 & 8,395 & 4,390 & 6,627 \\
\hline Amortizations & 1,572 & 1,913 & 2,155 & 2,125 & 2,116 & 2,238 & 2,225 \\
\hline Bonds & 0 & 0 & 0 & 0 & 0 & 1,463 & 0 \\
\hline Placements & 0 & 0 & 0 & 0 & 0 & 4,181 & 2,702 \\
\hline Amortizations & 0 & 0 & 0 & 0 & 0 & 2,718 & 2,702 \\
\hline Net domestic financing & 731 & 3,928 & 5,554 & 5,499 & 4,826 & 5,236 & 6,621 \\
\hline Net issuance of bonds & 3,119 & 2,019 & 4,388 & 4,500 & 4,800 & 5,171 & 5,620 \\
\hline Gross bond issuance & 5,308 & 3,851 & 5,172 & 6,219 & 6,519 & 6,500 & 6,945 \\
\hline Amortizations & 2,189 & 1,832 & 783 & 1,719 & 1,719 & 1,329 & 1,325 \\
\hline Other & -594 & -393 & 0 & 0 & 0 & 0 & 0 \\
\hline Use of government deposits & $-1,794$ & 2,302 & 1,166 & 999 & 26 & 65 & 1,001 \\
\hline Rest of nonfinancial public sector balance & 2,975 & 2,654 & 1,200 & 1,700 & 1,700 & 1,745 & 1,772 \\
\hline \multicolumn{8}{|l|}{ Consolidated nonfinancial public sector } \\
\hline Primary balance & 3,095 & 1,903 & $-4,097$ & $-3,173$ & $-4,355$ & $-1,348$ & $-3,205$ \\
\hline Interest & 3,892 & 4,026 & 4,374 & 5,060 & 5,050 & 5,760 & 6,045 \\
\hline Overall balance & -797 & $-2,123$ & $-8,472$ & $-8,233$ & $-9,405$ & $-7,107$ & $-9,250$ \\
\hline Central bank balance & 272 & 609 & -381 & -530 & -509 & -248 & -60 \\
\hline \multicolumn{8}{|l|}{ Memorandum items: } \\
\hline Nonfinancial public sector debt & 55,858 & 58,766 & 70,579 & 79,050 & 80,982 & 89,209 & 92,436 \\
\hline External & 31,667 & 32,556 & 39,981 & 43,951 & 45,584 & 48,939 & 51,418 \\
\hline Domestic & 24,191 & 26,210 & 30,598 & 35,098 & 35,398 & 40,269 & 41,018 \\
\hline Central government gross borrowing requirements & 7,533 & 8,522 & 12,611 & 13,777 & 14,940 & 15,137 & 17,275 \\
\hline Social spending & 12,022 & 13,080 & 16,165 & 18,004 & 18,004 & 19,193 & 19,493 \\
\hline GDP & 261,760 & 295,894 & 307,369 & 325,312 & 330,383 & 348,971 & 354,427 \\
\hline
\end{tabular}

Sources: Ministry of Finance; Bank of Guatemala; and Fund staff estimates and projections.

1/ Staff Report for the Third Review under the SBA. 
Table 3B. Guatemala: Public Sector Balance

\begin{tabular}{|c|c|c|c|c|c|c|c|}
\hline & 2007 & 2008 & 2009 & 20 & 10 & 20 & 11 \\
\hline & & & & $1 /$ & Rev. proj. & $1 /$ & Rev. proj. \\
\hline & & & $(\ln \mathrm{p}$ & ent of $C$ & GDP) & & \\
\hline Central Government & & & & & & & \\
\hline Total revenues & 12.8 & 12.0 & 11.1 & 11.3 & 11.3 & 11.5 & 11.7 \\
\hline Tax revenues & 12.1 & 11.3 & 10.3 & 10.6 & 10.6 & 10.8 & 10.8 \\
\hline Nontax revenues & 0.8 & 0.8 & 0.7 & 0.7 & 0.7 & 0.7 & 0.9 \\
\hline Total expenditures & 14.3 & 13.6 & 14.2 & 14.3 & 14.7 & 14.0 & 14.8 \\
\hline Current & 9.5 & 9.2 & 10.1 & 10.8 & 10.6 & 10.9 & 11.0 \\
\hline Wages & 3.1 & 3.1 & 3.6 & 3.7 & 3.8 & 3.8 & 3.8 \\
\hline Goods \& services & 1.3 & 1.8 & 1.8 & 2.0 & 1.8 & 2.0 & 2.1 \\
\hline Social security benefits & 0.8 & 0.8 & 0.9 & 1.0 & 1.0 & 1.0 & 1.1 \\
\hline Interest & 1.5 & 1.4 & 1.4 & 1.6 & 1.5 & 1.7 & 1.7 \\
\hline Transfers & 2.7 & 2.1 & 2.3 & 2.5 & 2.5 & 2.5 & 2.3 \\
\hline Other & 0.0 & 0.0 & 0.0 & 0.0 & 0.0 & 0.0 & 0.0 \\
\hline Capital & 4.8 & 4.5 & 4.1 & 3.5 & 4.1 & 3.1 & 3.8 \\
\hline of which: reconstruction & n.a. & n.a. & n.a. & 0.0 & 0.3 & 0.0 & 0.4 \\
\hline Primary expenditures & 12.8 & 12.3 & 12.8 & 12.8 & 13.2 & 12.4 & 13.1 \\
\hline Primary balance & 0.0 & -0.3 & -1.7 & -1.5 & -1.8 & -0.9 & -1.4 \\
\hline Overall balance & -1.4 & -1.6 & -3.1 & -3.1 & -3.4 & -2.5 & -3.1 \\
\hline Overall balance (without reconstruction) & n.a. & n.a. & n.a. & -3.1 & -3.1 & -2.5 & -2.7 \\
\hline Financing & 1.4 & 1.6 & 3.1 & 3.1 & 3.4 & 2.5 & 3.1 \\
\hline Net external financing & 1.2 & 0.3 & 1.3 & 1.4 & 1.9 & 1.0 & 1.2 \\
\hline Loans & 1.2 & 0.3 & 1.3 & 1.4 & 1.9 & 0.6 & 1.2 \\
\hline Disbursements & 1.8 & 0.9 & 2.0 & 2.0 & 2.5 & 1.3 & 1.9 \\
\hline Amortizations & 0.6 & 0.6 & 0.7 & 0.7 & 0.6 & 0.6 & 0.6 \\
\hline Bonds & 0.0 & 0.0 & 0.0 & 0.0 & 0.0 & 0.4 & 0.0 \\
\hline Placements & 0.0 & 0.0 & 0.0 & 0.0 & 0.0 & 1.2 & 0.8 \\
\hline Amortizations & 0.0 & 0.0 & 0.0 & 0.0 & 0.0 & 0.8 & 0.8 \\
\hline Net domestic financing & 0.3 & 1.3 & 1.8 & 1.7 & 1.5 & 1.5 & 1.9 \\
\hline Net issuance of bonds & 1.2 & 0.7 & 1.4 & 1.4 & 1.5 & 1.5 & 1.6 \\
\hline Gross bond issuance & 2.0 & 1.3 & 1.7 & 1.9 & 2.0 & 1.9 & 2.0 \\
\hline Amortizations & 0.8 & 0.6 & 0.3 & 0.5 & 0.5 & 0.4 & 0.4 \\
\hline Other & -0.2 & -0.1 & 0.0 & 0.0 & 0.0 & 0.0 & 0.0 \\
\hline Use of government deposits & -0.7 & 0.8 & 0.4 & 0.3 & 0.0 & 0.0 & 0.3 \\
\hline Rest of nonfinancial public sector balance & 1.1 & 0.9 & 0.4 & 0.5 & 0.5 & 0.5 & 0.5 \\
\hline Consolidated nonfinancial public sector & & & & & & & \\
\hline Primary balance & 1.2 & 0.6 & -1.3 & -1.0 & -1.3 & -0.4 & -0.9 \\
\hline Interest & 1.5 & 1.4 & 1.4 & 1.6 & 1.5 & 1.7 & 1.7 \\
\hline Overall balance & -0.3 & -0.7 & -2.8 & -2.5 & -2.8 & -2.0 & -2.6 \\
\hline Central bank balance & 0.1 & 0.2 & -0.1 & -0.2 & -0.2 & -0.1 & 0.0 \\
\hline Memorandum items: & & & & & & & \\
\hline Nonfinancial public sector debt & 21.3 & 19.9 & 23.0 & 24.3 & 24.5 & 25.6 & 26.1 \\
\hline External & 12.1 & 11.0 & 13.0 & 13.5 & 13.8 & 14.0 & 14.5 \\
\hline Domestic & 9.2 & 8.9 & 10.0 & 10.8 & 10.7 & 11.5 & 11.6 \\
\hline Central government gross borrowing requirements & 2.9 & 2.9 & 4.1 & 4.2 & 4.5 & 4.3 & 4.9 \\
\hline Social spending & 4.6 & 4.4 & 5.3 & 5.5 & 5.4 & 5.5 & 5.5 \\
\hline
\end{tabular}


Table 4. Guatemala: Monetary Sector Survey

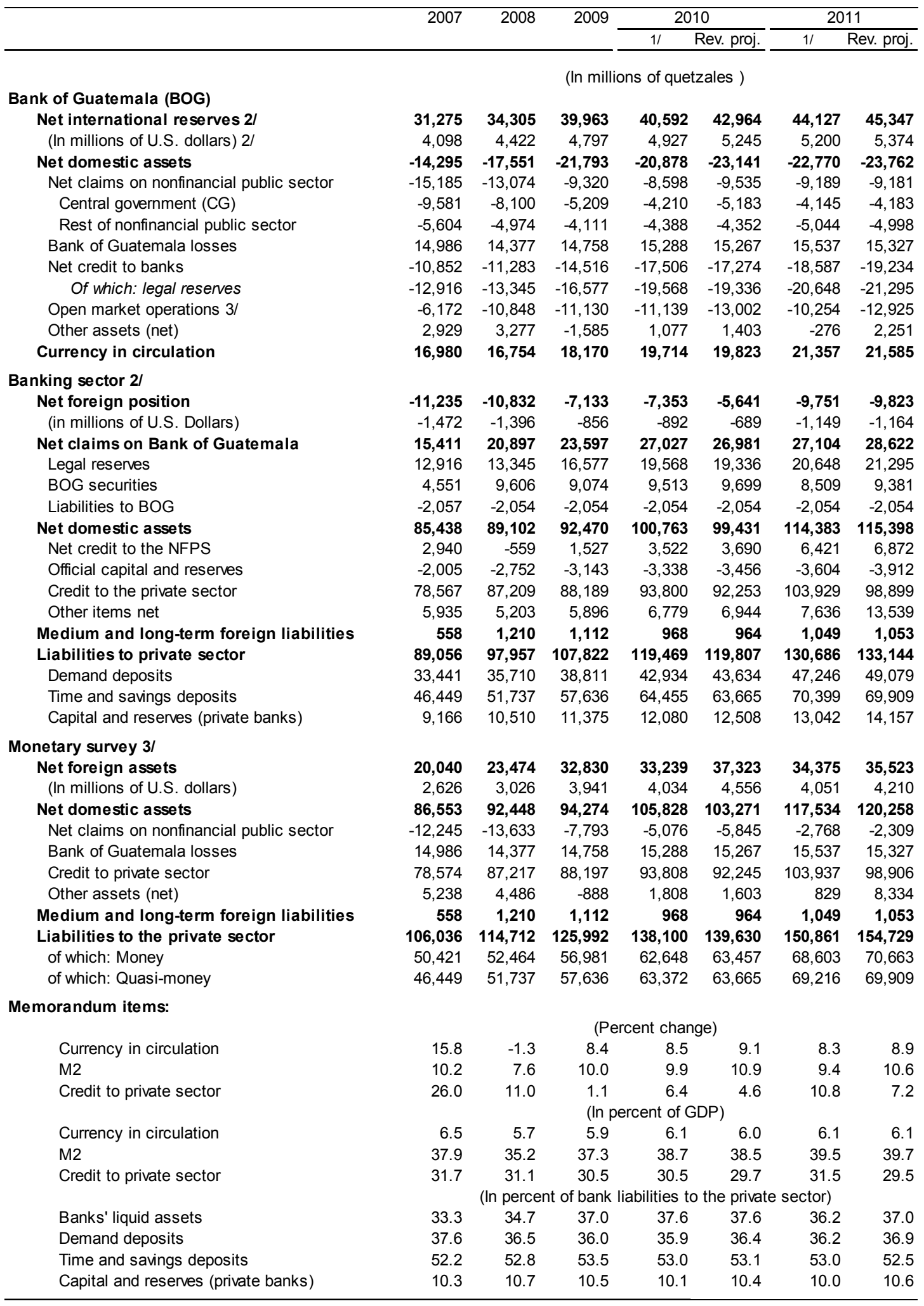

Sources: Bank of Guatemala; and Fund staff estimates.

1/ Staff Report for the Third Review under the SBA.

2/ Program definition which includes foreign currency liabilities of the central bank to financial institutions.

3 / Includes open market placements with the private sector (financial and nonfinancial). 
Table 5. Guatemala: Financial Soundness Indicators

\begin{tabular}{lrrrrr}
\hline & 2006 & 2007 & 2008 & 2009 & $\begin{array}{r}2010 \\
\text { June }\end{array}$ \\
\hline On-shore banks & & & & & \\
Statutory capital to risk-weighted assets & 13.6 & 13.8 & 13.5 & 15.4 & 15.1 \\
Nonperforming loans net of provisions to capital & 7.5 & 6.2 & 3.6 & 1.8 & 0.0 \\
Nonperforming loans to total gross loans & 3.4 & 2.6 & 2.3 & 2.7 & 2.8 \\
Cash to total deposits & 21.2 & 20.8 & 19.4 & 21.6 & 22.3 \\
Return on assets & 1.2 & 1.5 & 1.7 & 1.6 & 1.9 \\
Return on equity & 15.0 & 16.8 & 16.3 & 15.7 & 18.1 \\
Foreign currency-denominated loans to total loans & 30.2 & 33.2 & 33.6 & 30.6 & 28.5 \\
Foreign currency-denominated liabilities to total liabilities & 21.6 & 25.1 & 24.3 & 23.9 & 24.1 \\
Off-shore banks & & & & 14.9 & 10.9 \\
Statutory capital to risk-weighted assets & 14.2 & 15.0 & 14.7 & 8.4 \\
Nonperforming loans to total gross loans & 2.9 & 2.9 & 2.2 & 2.3 & 2.3 \\
Return on assets & 2.0 & 2.2 & 1.5 & 1.4 & 1.3 \\
Return on equity & 18.8 & 19.4 & 14.2 & 12.8 & 12.5 \\
Total assets off-shore banks to total assets on-shore banks & 18.9 & 16.8 & 16.1 & 16.5 & 15.8 \\
\hline
\end{tabular}

Sources: Superintendency of Banks; Bank of Guatemala; and Fund staff estimates.

Table 6. Guatemala: Indicators of External Vulnerability

\begin{tabular}{|c|c|c|c|c|c|}
\hline & 2006 & 2007 & 2008 & $2009^{-}$ & $\begin{array}{l}\text { Proj. } \\
2010 \\
\end{array}$ \\
\hline \multicolumn{6}{|l|}{ External indicators } \\
\hline Merchandise exports (12-month percentage change) & 11.4 & 14.8 & 12.4 & -6.6 & 11.8 \\
\hline Traditional merchandise exports (12-month percentage change) & 5.0 & 25.2 & 18.5 & 7.5 & 10.1 \\
\hline Nontraditional merchandise exports (12-month percentage change) & 13.3 & 12.0 & 10.5 & -11.2 & 12.5 \\
\hline Merchandise imports (12-month percentage change) & 13.3 & 14.0 & 7.6 & -20.8 & 17.3 \\
\hline Imports of oil and lubricants (12-month percentage change) & 18.6 & 29.1 & 17.4 & -23.1 & 15.8 \\
\hline Non-oil imports (12-month percentage change) & 12.4 & 11.1 & 5.4 & -20.2 & 17.7 \\
\hline Terms of trade (12-month percentage change) & -2.7 & -0.3 & -1.4 & 3.8 & -2.5 \\
\hline Current account balance (in percent of GDP) & -5.0 & -5.2 & -4.8 & -0.6 & -2.9 \\
\hline Capital and financial account balance (in percent of GDP) & 4.4 & 4.7 & 4.1 & -0.2 & 3.6 \\
\hline \multicolumn{6}{|l|}{ Net international reserves } \\
\hline In millions of U.S. dollars & 3,878 & 4,098 & 4,421 & 4,797 & 5,245 \\
\hline In percent of M2 & 36.4 & 33.3 & 33.2 & 34.9 & 33.9 \\
\hline In percent of base money & 111.0 & 105.2 & 113.2 & 115.2 & 112.4 \\
\hline In percent of short-term external debt on a remaining maturity basis & 117.6 & 102.1 & 105.3 & 138.1 & 139.0 \\
\hline In months of next-year's imports of goods and nonfactor services & 3.2 & 3.2 & 4.3 & 4.0 & 4.0 \\
\hline \multicolumn{6}{|l|}{ External indebtness indicators } \\
\hline Total external debt (in percent of GDP) & 34.3 & 35.0 & 32.5 & 29.4 & 29.8 \\
\hline External private sector debt (in percent of GDP) & 21.2 & 22.6 & 21.2 & 16.5 & 16.2 \\
\hline External public sector debt (in percent of GDP) & 13.1 & 12.4 & 11.2 & 13.0 & 13.6 \\
\hline \multicolumn{6}{|l|}{ Public sector external interest payments in percent of exports } \\
\hline of goods and nonfactor services & 3.6 & 3.9 & 3.0 & 3.4 & 3.6 \\
\hline $\begin{array}{l}\text { Public sector external amortization payments in percent of exports } \\
\text { of goods and services }\end{array}$ & 4.2 & 5.2 & 3.2 & 3.7 & 3.3 \\
\hline
\end{tabular}

Sources: Bank of Guatemala; and Fund staff estimates. 
Table 7. Guatemala: Schedule of Purchases under the Stand-By Arrangement

\begin{tabular}{|c|c|c|c|c|c|}
\hline \multirow[b]{2}{*}{ Date } & \multirow[b]{2}{*}{ Conditions for purchase } & \multicolumn{4}{|c|}{ Purchase } \\
\hline & & $\begin{array}{c}\text { Million } \\
\text { SDR }\end{array}$ & $\begin{array}{l}\text { Million } \\
\text { US\$ } 1 /\end{array}$ & $\begin{array}{l}\text { Percent } \\
\text { of Quota }\end{array}$ & $\begin{array}{c}\text { Percent of } \\
\text { Total } \\
\text { Access }\end{array}$ \\
\hline April 22, 2009 & Board approval of the SBA & 420.40 & 635.68 & 200.00 & 66.67 \\
\hline September 22, 2009 & $\begin{array}{l}\text { First review, based on end-June } 2009 \text { performance } \\
\text { criteria }\end{array}$ & 42.04 & 63.57 & 20.00 & 6.67 \\
\hline December 15, 2009 & $\begin{array}{l}\text { Second review, based on end-September } 2009 \\
\text { performance criteria }\end{array}$ & 42.04 & 63.57 & 20.00 & 6.67 \\
\hline February 15, 2010 & $\begin{array}{l}\text { Observance of end-December } 2009 \text { performance } \\
\text { criteria }\end{array}$ & 42.04 & 63.57 & 20.00 & 6.67 \\
\hline June 15, 2010 & $\begin{array}{l}\text { Third review, based on end-March } 2010 \text { performance } \\
\text { criteria }\end{array}$ & 42.04 & 63.57 & 20.00 & 6.67 \\
\hline September 15, 2010 & $\begin{array}{l}\text { Fourth review, based on end-June } 2010 \text { performance } \\
\text { criteria }\end{array}$ & 42.04 & 63.57 & 20.00 & 6.67 \\
\hline Total & & 630.60 & 953.52 & 300.00 & 100.00 \\
\hline
\end{tabular}

Source: Fund staff estimates.

1/ US\$/SDR exchange rate of 0.661339 as of September 8, 2010.

Table 8. Guatemala: Indicators of Fund Credit 2009-2016 1/

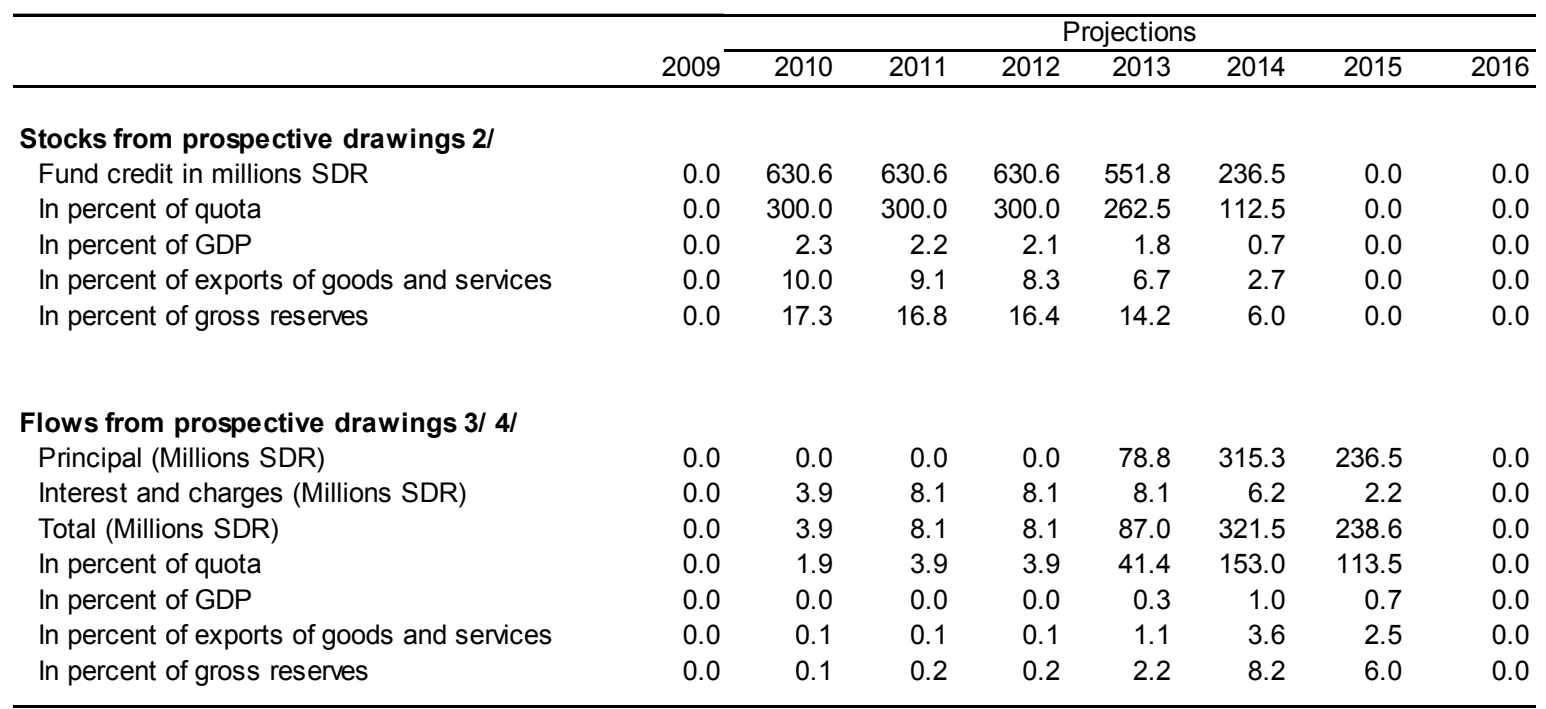

Sources: Bank of Guatemala; IMF Finance Department; and Fund staff estimates.

1/ Assumes a US\$/SDR exchange rate of 0.661339 as of September 8, 2010.

2/ End of period.

3/ At a constant basic rate of charge in the GRA of 1.29 percent plus 0.01 basis points for burden sharing.

4/ Excluding commitment charges. 


\section{ATTACHMENT 1: LETTER OF INTENT}

Guatemala City, September 13, 2010

Mr. Dominique Strauss-Kahn

Managing Director

International Monetary Fund

Washington, D.C., 20431

Dear Mr. Strauss-Kahn:

1. The Stand-By Agreement approved by the IMF Executive Board on April 22, 2009, continues to be implemented satisfactorily. All end-June quantitative performance criteria were met (Table 1). In particular, we have complied with the targets on net international reserves and the overall balance of the central government; government deposits at the central bank were above the indicative target, and consumer price inflation at end-June stood at 4.1 percent (year-over-year), within the inner consultation band set in the program.

2. The recovery of the Guatemalan economy is firming up. Although the natural disasters that hit the country in late May caused human losses and had a negative impact on the economy, they did not derail the recovery. We are confident that economic growth will exceed 2 percent in 2010 and that inflation will remain within the target band of 4-6 percent set by the Monetary Board. At present, growth in exports and imports is accelerating, remittances are recovering, and international reserves are well above end-2009 levels. The fiscal outturn in the first half of 2010 was better than envisaged, with the deficit of the central government reaching 0.9 percent of annual GDP ( 0.6 percent of GDP lower than projected). The financial system remains resilient, and credit to the private sector in local currency is gradually picking up.

3. In light of this performance and our continued commitment to the program, we request completion of the fourth and final review under the SBA. Our intention remains to treat the remainder of the arrangement as precautionary.

4. We remain committed to the broad macroeconomic policy and reform agenda spelled out in previous Letters of Intent as the program comes to an end in October 2010. Looking ahead, we intend to continue our close and productive policy dialogue with the Fund.

Sincerely yours,

/s/

Edgar Alfredo Balsells Conde Minister of Finance
Maria Antonieta del Cid Navas de Bonilla

President, Central Bank of Guatemala 
Table 1. Guatemala: Quantitative Performance Criteria, Indicative Targets, and Inflation Consultation Clause

\begin{tabular}{|c|c|c|c|c|}
\hline & \multirow{3}{*}{$\frac{2009}{\text { End-December }}$} & \multicolumn{3}{|c|}{2010} \\
\hline & & \multirow[t]{2}{*}{ End-March } & \multicolumn{2}{|c|}{ End-June } \\
\hline & & & $1 /$ & Observed \\
\hline \multicolumn{5}{|l|}{ Performance Criteria } \\
\hline Overall balance of the central government, floor (millions of quetzales) $2 /$ & $-9,684$ & $-1,199$ & $-5,000$ & $-3,095$ \\
\hline Net international reserves, floor (millions of US\$) & 4,797 & 5,119 & 4,000 & 5,307 \\
\hline Accumulation of external arrears $3 /$ & 0 & 0 & 0 & 0 \\
\hline \multicolumn{5}{|l|}{ Indicative Targets } \\
\hline Central government deposits at Banguat, floor (millions of quetzales) & 5,209 & 5,365 & 5,000 & 8,788 \\
\hline \multicolumn{5}{|l|}{ Consultation clause on inflation $4 /$} \\
\hline Outer band, upper limit & 3.8 & 6.5 & 7.5 & 7.5 \\
\hline Inner band, upper limit & 2.8 & 5.5 & 6.5 & 6.5 \\
\hline Inner band, low er limit & -1.2 & 1.5 & 2.5 & 2.5 \\
\hline Outer band, low er limit & -2.2 & 0.5 & 1.5 & 1.5 \\
\hline \multicolumn{5}{|l|}{ Memorandum item: } \\
\hline Actual inflation & -0.3 & 3.9 & $\ldots$ & 4.1 \\
\hline
\end{tabular}

1/ Staff Report for the Third Review under the SBA.

2/ Cumulative from end of preceding year.

3/ Continuous performance criterion.

4/ Deviations from the band's limits will trigger consultations w ith the Fund, as indicated in the TMU. 
Press Release No. 10/362

International Monetary Fund

FOR IMMEDIATE RELEASE

Washington, D.C. 20431 USA

September 28, 2010

\section{IMF Concludes Fourth Review Under Stand-By Arrangement with Guatemala}

The Executive Board of the International Monetary Fund (IMF) today concluded the fourth review of Guatemala's economic performance under a program supported by an 18-month Stand-By Arrangement (SBA). The arrangement, in the amount equivalent to SDR 630.6 million (about US\$974.7 million) was approved on April 22, 2009 (see Press Release No. 09/142). The Guatemalan authorities intend to continue treating the arrangement as precautionary.

Following the Executive Board's discussion on Guatemala, Mr. Murilo Portugal, Deputy Managing Director and Acting Chair, stated:

"Guatemala's economic recovery has continued despite the natural disasters that hit the country in May. The authorities' proactive policy response to the global crisis, supported by a Stand-By Arrangement with the Fund, has provided a solid foundation for this outcome. Real GDP growth is expected to firm up, the balance of payments position is strengthening, the financial system remains resilient, and risks to the outlook have declined further.

"Performance under the program has remained strong. All end-June 2010 quantitative performance criteria were met and inflation remained within the inner consultation band agreed in the program. The 18-month Stand-By Arrangement, ending October 21, is expected to continue to be treated as precautionary.

"The small withdrawal of fiscal stimulus previously envisaged for 2010 will be postponed to accommodate the relief and reconstruction expenditures related to the natural disasters. Implementing a comprehensive revenue-enhancing reform remains a priority. Higher revenues will help stabilize the public debt-to-GDP ratio and avoid the burden of fiscal consolidation from falling disproportionately on social and capital expenditures. It is also crucial to find a lasting solution to the problem of domestic arrears which weakens the budgetary and fiscal framework.

Washington, D.C. 20431 • Telephone 202-623-7100 • Fax 202-623-6772 • www.imf.org 
"The monetary policy stance remains broadly appropriate. It is important that the authorities remain vigilant and ready to tighten the stance if inflationary pressures emerge. Exchange rate flexibility continues to be essential to absorb shocks and enhance the inflation-targeting framework.

"Progress continues with the financial sector reform agenda, including on regulations on liquidity and foreign-currency credit risk management, provisioning of nonperforming loans, and the approval of the law governing the insurance sector. Congressional passage of the amendments to the banking law and the development of a banking resolution plan would further efforts to increase the resilience of the financial system," Mr. Portugal said. 


\section{Statement by Ramón Guzmán, Executive Director for Guatemala September 27, 2010}

We thank the staff for a concise and well-balanced report. Our authorities broadly agree with the staff's appraisal and recommendations. We would also like to thank management and staff for the continued engagement and willingness to carry out a productive policy dialogue with our authorities throughout the program, and Directors for their constant support.

Our authorities would like to reiterate that Fund's support played a crucial role in maintaining confidence and macro-financial stability during the recent global crisis.

Performance under the Stand-By Arrangement has been strong. All the end-June quantitative performance criteria were met; particularly, our authorities complied with the targets on net international reserves and the overall balance of the central government. Government deposits at the Central Bank were well above the indicative target and annual inflation remained within the inner consultation band set in the program.

\section{Recent Developments}

The natural disasters that hit the country recently caused human loses and had a negative impact on the economy; however, they did not deviate the economic recovery path. The monthly index of economic activity (IMAE) increased 3.1 percent $(y / y)$ in June in line with the expected economic growth for the whole year of more than 2 percent. Headline inflation was 4.1 percent as of end-August, and we expect it will remain within the target of 5 percent $+/-1$ percentage points established by the Monetary Board. Currently, growth in exports and imports is accelerating, remittances are recovering, and international reserves are well above end-2009 levels. The fiscal outturn in the first semester of 2010 was better than envisaged, with the deficit of the central government reaching 0.9 percent of GDP, 0.6 percent lower than programmed. The banking system remains liquid and well capitalized and credit to the private sector in domestic currency has begun to gradually recover.

\section{Fiscal Policy}

Although challenges on the revenue front persist, our fiscal authorities remain committed to maintaining prudent policies. Key priorities in the short-term are to accommodate relief and reconstruction spending related to the recent natural disasters, seek congressional approval of the already submitted 2011 budget, avoid domestic arrears by the government, control nonpriority spending, and seek congressional support to the anti-evasion law.

In that context, our authorities raised their 2010 target for central government deficit to 3.4 percent of GDP (3.1 percent previously) to face demand for relief and reconstruction spending. For 2011 the budget draft envisages the start of fiscal consolidation, with a central government deficit of 3.1 percent of GDP (2.7 percent of GDP excluding reconstruction expenditures). Although we see merit in staff's recommendation of having a more ambitious pace of consolidation, we believe it is not feasible in the short-term (at least not without 
reducing social and capital expenditure significantly) having in mind the ongoing spending pressures related to the natural disasters.

From a medium-term perspective, our fiscal authorities are of the view that fiscal consolidation should be fostered by further structural changes. In that context, given that political resistance to a comprehensive tax reform prevails, as a first step our authorities intend to work with Congress to build support for some measures included in the draft law submitted in November 2009, including increases in income and stamp tax rates. Authorities will also seek congressional approval of measures to strengthen tax administration. Those measures are aimed at avoiding a contraction in social and capital expenditures during fiscal consolidation.

The authorities are aware of the importance of implementing measures to avoid new arrears and regularize the outstanding debt stock. In that sense, they intend to undertake several actions recommended by the recent Fund's technical assistance mission on domestic arrears.

\section{Monetary and Exchange Rate Policies}

The monetary policy rate has been kept at 4.5 percent since September 2009, given that inflation expectations have broadly converged to the upper limit of the target set by the Monetary Board (6 percent). Moreover, the authorities consider that inflation expectations around the target, a sluggish credit growth, and a negative output gap are reasonable indicators that the current monetary policy stance is broadly adequate. However, they stand ready to adjust their policy stance if conditions change.

The Central Bank has been improving its monetary operations and plans to implement a framework based on an overnight interest rate. A transitional framework may come into place in October, bearing in mind that the upgraded framework will begin to function when the Central Bank and markets are confident that procedures and systems work efficiently. We believe that these changes will contribute to enhance the inflation targeting regime and the monetary transmission mechanism.

Our authorities remain committed to maintaining the exchange rate flexibility, which has proved effective to help absorb external shocks. In that sense, the Central Bank's intervention in the foreign exchange market is aimed at moderating exchange rate volatility using a rulesbased scheme.

\section{Financial Policy}

The banking system remains liquid and well capitalized. The authorities have recently adopted regulations on liquidity and foreign currency credit risk management and have made further progress towards full provisioning of non-performing loans. In addition, in July Congress approved a law governing the insurance sector activity, which enhances the legal capacity of the Superintendency of Banks to effectively supervise insurance intermediaries.

The authorities have also been working in preparing regulations to further strengthen information technology risk, banks risk governance and comprehensive risk management; 
those regulations are expected to be approved by end-2010. They will persist in seeking congressional approval of the reforms to the banking law, which are instrumental to further increase the resilience of the banking sector.

Finally, our authorities want to underscore that the Fund-supported program has also importantly contributed to achieve their economic program goals and intend to continue to treat the remainder of the arrangement as precautionary. Looking forward, they would like to continue the close and fruitful dialogue with the Fund. 